\title{
Conflicting Voices in HIV/AIDS Education of the South African Youth: School Culture Versus South African Traditional Healers Using Ancestral Worship
}

\author{
Miriam Siwela* and Cecelia Jansen
}

\author{
University of South Africa, South Africa
}

\begin{abstract}
The United Nations Agency of International Development (2013) states that an estimated 24.7 million people are living with HIV in sub-Saharan Africa, nearly $71 \%$ of the global total. The 2.9 million are young people aged 15-24 and this generation is living in South Africa. These alarming statistics reveal that various HIV/AIDS prevention strategies have met limited success. The question arises: why? The South African youth face the dilemma that they receive conflicting messages from two opposing sources, each with a strong persuasive pull of its own where HIV/AIDS education is concerned. On one hand, the voice of modern medical science proclaims that the disease is caused by a viral infection that suppresses the victim's immune response, while on the other hand spiritual voices of African traditional healers offer explanations such as witchcraft or angry ancestors. This article is an attempt to discover whether either or neither of these voices is gaining ground amongst the youth. This article is based on a qualitative phenomenological study conducted at an urban secondary school in Pretoria, South Africa. Empirical findings resulted from the purposive sampling by means of interviews conducted with two focus groups of teachers, three focus groups of grade 12 school learners and one school principal. This was followed by thematic analysis involving the identifying, analysing and reporting patterns (themes) within data. Facts emerging from the research were that conflicting voices are stressful for young people who are subjected to societal pressure to conform and comply with unrealistic expectations. The South African social culture of ancestral worship is very powerful, yet school culture has significant countervailing influence that sheds liberating "light" where gloom of fear, uncertainty and superstition used to prevail. It is critical to note in this regard, for instance, that where HIV/AIDS remedies are concerned, there is no standardised solution for the 'entire world' and that a unique situation prevails in the South African social cultural environment where ancestral worship exerts a critically real influence on people's response to the threat of HIV/AIDS.
\end{abstract}

Keywords: School culture, youth, South African social culture, HIV/AIDS beliefs, misconceptions, traditional healers, authoritative voice.

\section{INTRODUCTION}

The youth of South Africa face the dilemma of being pulled apart by conflicting messages from opposing forces, each with a strong persuasive pull of its own where HIV/AIDS education is concerned. On the one hand, modern medical science proclaims that the disease is caused by a viral infection that suppresses the victim's immune response, while on the other hand; spiritual explanations are offered by the traditional South African culture of ancestral worship where factors such as witchcraft or angry ancestors feature dominantly (Wood, 2008:38). These influences are confusing to the young people who need special guidance to find their way through thickets of fear, suspicion and clouds of uncertainty, engendered by the swirling chaos of "traditional beliefs" that thrive on ignorance.

There is abundant literature on HIV/AIDS around the world, especially from The World Health Organisation (WHO) and the Joint United Nations

*Address correspondence to this author at the University of South Africa, South Africa; Tel: +27(0) 73677 0094; E-mail: Miriam.siwela4@gmail.com
Programme on HIV and AIDS, or UNAIDS, the main advocate for accelerated, comprehensive and coordinated global action on the HIV/AIDS epidemic. The UNAIDS report on the global aids epidemic $(2010: 9$ - 11) has stated that for the estimated 33.3 million people living with HIV after over 30 years into a very complex epidemic, the gains are real but still fragile. The biggest epidemics in sub-Saharan Africa are in South Africa, Zambia, and Zimbabwe. The report goes further to state that out of an estimated HIV/AIDS infection rate 33.3 million in 2009 , a staggering 22,5 million at that stage occurred in sub-Saharan Africa, the highest incidence of 5.6 million occurred in South Africa (UNAIDS, 2010:182). The question that arises is: Why has HIV/AIDS spread faster in Africa than on any other continent, despite the same international strategies and progressive government polices of abstinence, one sexual partner, condom use and availability of antiretroviral (ARVs) drugs?

This article is based on qualitative research was conducted in Pretoria, South Africa, exploring the perceptions of grade 12 school learners that were exposed to two main conflicting voices; school culture and on the other hand the social culture of traditional ancestral worship. The article seeks to contribute to the 
attempt by Africans to find solutions to challenges in their continent through the effective use of educational research.

\section{BACKGROUND}

It is not uncommon to hear the assertion among adherents of South African cultures that the so-called traditional healers ('sangomas' in isiZulu and "inyangas") can cure HIV/AIDS using locally available herbs known as 'traditional medicine' or 'umuthi'. Pope, White and Maslow (2009:261) note that 'umuthi' (traditional medicine) consists of plants, and animal products that are specially prepared to address a particular illness or symptom, and that failure to pay due deference to ancestors (genealogical provenance) is blamed as one of the causes of HIV/AIDS.

For the purpose of this study, the term 'traditional healer' will refer to African traditional healers who possess powers of divination (i.e. mainly black South African 'sangomas', although there is evidence of the existence of white South African traditional healers). The article excludes African herbalists ('inyanga' who use herbal medicine without talking to the dead), and moreover not to be confused with scientific health practitioners who practice according to formal medical science.

As far back as 2009, Nolaki (in Cullinan and Thom (2009:143), has stated that at least $70 \%$ of all South Africans consult traditional healers on matters relating to placating or petitioning ancestral spirits and use various herbal remedies at some time or other. The traditional medicines sector in South Africa is worth R3 billion a year (over 5 per cent of the national health budget), and serves almost 27 million consumers. However, this article is not focusing on the merits and demerits of traditional medicines, but on the conflicting voices as experienced by grade 12 learners, making HIV/AIDS programmes relatively ineffectual.

It is interesting to note that South Africa, unlike many of its counterparts in sub-Saharan Africa, were rarely short of assistance in the war against the epidemic. In the early 1980s, there was evidence of high levels of ignorance and denial about HIV/AIDS. At the beginning of 1990, the Maputo Declaration on HIV/AIDS in Southern Africa confirmed its commitment on strategies against this pandemic. The newly unbanned ANC met with the apartheid era national Department of Health in 1991, and this cooperation led to the forming of the National HIV/AIDS Community of
South Africa (NACOSA) in 1992. This body consisted of various strong, technically proficient and widely experienced NGOs, anti-apartheid political groupings, academics and health professionals dealing with HIV/AIDS (Schneider \& Stein, 2001). Today, the NACOSA website states that it was created as an outcome of a national conference in 1991 to lobby for and develop the first National AIDS Plan for South Africa. NACOSA is now a network of more than 1,500 HIV, AIDS, TB and other related stakeholders working in communities across South Africa (http://www.nacosa.org.za/about/who-we-are.aspx).

The National AIDS Plan (NAP) adopted in 1994 was the first national policy response by the government of South Africa, although, by then HIV/AIDS had caused widespread misery, fear and death. Years later, after the dismal failure of NAP, the South Africa National AIDS Council (SANAC) was introduced as the highest body advising the government on HIV/AIDS policy issues, tasked with monitoring implementation in all sectors with partnership with various non-state organisations. The internal anti-apartheid movement and the ANC acknowledged the epidemic and began to address the issue of HIV/AIDS. The various organisations were all expected to work cooperatively with the government in order to rapidly implement South Africa's new AIDS plan (Schneider \& Stein, 2001). SANAC, comprised over 16 government representatives from the various ministries and 17 representatives of civil organisations. HIV/AIDS continued to increase despite the national policies, and this gave rise to the forming of the National HIV/AIDS/STI Strategic Plan for South Africa: 20002005. Internationally, the Global Plan towards eliminating new HIV infections among children by 2015 and keeping their mothers alive was launched in July 2011 at the United Nations General Assembly HighLevel Meeting on AIDS. It is important to note that it is unfortunate that crisis situations are fully developed and expressed before remedial action is taken. In the end, everything is always a patch job and improvements are always prospective. This was due to strategy implementation lags, which led to ineffective efforts to remedy the situation.

Furthermore, according to Ndaki (Cullinan \& Thom, 2009:148) the Traditional Health Practitioners Act, which provides a framework for regulating the sector, including registering a practitioners' council, was signed into law by President Thabo Mbeki in 2008. In view of the HIV/AIDS crisis and new legislation relating to the disease, school managers have a definite role to 
play in educating parents and learners to ensure the empowerment of learners becomes a successful global campaign - with specific reference to the youth.

As early as 1985 , research on effective schools lent credence to the view that schools can be organised, with the principal in the lead, to improve school culture, and therefore learner behaviour (Firestone \& Wilson, 1985:25). The quality of educational leadership has to be high in order to cope with the critical issues affecting learners' scientific education and training. The role of the principal in the educational context includes empowering both educators and learners in the fight against HIV/AIDS. An understanding of both school culture and HIV/AIDS is necessary for the development of effective instructional methods and techniques to deal appropriately with these misconceptions. As noted by Van Deventer and Kruger (2003:5), the culture of a school is a very important aspect of school life and has a profound effect on all other elements of education.

South African youth still face significant challenges such as high unemployment rates, high HIV infection and increased in youth- headed households for the ages 15-24 (UNFPA South Africa, 2014).Today's youth are the generation who are privileged, for the first time in history, with a superabundance of information, communication and technology (ICT). They are even experiencing the brand-new phenomenon of information overload via internet, television, libraries, oral transmission and school. It is important to empower African youth to be skilled at recognising problems and devising solutions in the $21^{\text {st }}$ century era. South Africa's population is largely made up of young people; those who are below the age of 35 years constitute about $66 \%$ per cent of the total population. With over 54 million South Africans, 18.5 per cent are between the ages 10-19; and 24 per cent are aged 1524 (Stats SA: 2015), mid-year population estimate.

\section{LITERATURE REVIEW}

\section{Introduction}

A study in South Africa conducted by a UNAIDS collaborator through the Centre for the AIDS Programme of Research in South Africa (CAPRISA) in 2015, found that HIV prevalence increased rapidly among older school-going adolescents in a rural district. In one school, HIV prevalence rose from an average $1.9 \%$ [0.7-4.6\%] among adolescent girls aged $12-14$ to $12.2 \%$ [4.6-27.0\%] among adolescent girls just 5 years older.
However, among young people in 15 of the most severely affected countries, HIV prevalence has fallen by more than $25 \%$ as these young people have adopted safer sexual practices. Similar to treatment access, there is considerable room for continued improvement. Young people's knowledge of HIV is increasing but needs to grow further. There is a crisis in prevention as it is estimated that 1000 people in South Africa are infected by HIV/AIDS every day (UNAIDS 2010:10). The purpose of the research under review is therefore to contribute towards the strategic solutions required to curb the spread of HIV/AIDS by determining the impact of formal schooling on learners' perceptions of and attitudes towards the issue of HIV/AIDS.

The main HIV/AIDS prevention strategies advocated by international donor agencies for subSaharan African population, such as condom use, abstinence and faithfulness to a particular partner provided it is reciprocal (Youde, 2007: 8 ; Van Dyk, 2008:209) have had little success. The UNAIDS (2013:30) further reported that:

Home to just over $5 \%$ of the global
population, eastern and sub-Saharan
Africa accounted for close to $50 \%$ of all
people living with HIV (17.1 million of the
estimated global total of 34.0 million
[31.4-35.9 million]) and $48 \%$ of the
estimated 2.5 million [2.2-2.8 million] new
HIV infections in 2011 .

The background report revealed that the South African government did put in place various national HIV/AIDS policies to curb the disease, yet HIV/AIDS statistics continue to show a disturbing growth pattern, especially in Sub- Saharan Africa. The question arises once again: why?

\section{The Voice of School Culture on HIV/AIDS Education}

For the present purpose the researchers will refer to the working definition of school culture as formulated by Van der Westhuizen et al. (2007:620). The cultural environment or milieu determines the behaviour of its members. A culture exerts pressure on members to conform to specific standards and validate expectations in terms of the interests of the specific community. For the present purpose school culture is deemed to be synonymous with organisational culture. The researchers accept the assertion by Van Deventer and Kruger (2003:19) that culture in its widest social sense is established and maintained through a system of rites 
and rituals, patterns of communication, beliefs, expected patterns of behaviour and perceptions of the psychological contract that pervasively influence learners' behaviour and actions. The school's environment can play a vital role to reinforce behaviour and beliefs (Van Deventer \& Kruger 2003:19).

Kruger (2002:20) notes that values, traditions and beliefs, often manifested in relationships, architecture, symbols, myths and organisational structure, are all part of the culture of an organisation. The common element in the many definitions of culture relates to the values and norms prevailing at the school. These result in specific beliefs and views "which form the background for all behaviour in the school (Van der Westhuizen et al. (2007:129). The ability of a school to maintain a culture that is dynamic and enlightened about HIV/AIDS will have a positive and meaningful effect on learners, and subsequently on society as a whole, where AIDS prevention is concerned.

South Africa is a diverse and multicultural country, with an equally diverse educational and socio-cultural environment. A school environment which empowers youth, making it easier for them to understand HIV/AIDS and its attendant issues and challenges, needs to be fostered across South Africa. Educational leaders who are interested in changing their school culture should first try to understand the existing culture. Cultural forms such as routines, ceremonies, rituals, traditions, myths, or subtle differences in school language can provide clues that could be helpful in bringing about cultural change that assist in the achievement of desirable educational objectives, thus enabling the appropriate management of HIV/AIDS (Van Deventer \& Kruger (2003:23). There is an urgent need to address the influence that schools can exert on the youth in terms of understanding HIV/AIDS prevention mechanisms. Formal factual and scientific education has been and will always be the main vehicle of development.

Far from ignoring the disturbing HIV/AIDS statistics, an effective school leader must become directly involved in the 'war' against HIV/AIDS. According to Okumbe (1999:86), leadership is the process of encouraging others to work towards objectives that will transform the organisation's potential into reality. The most effective change in school culture happens when principals, educators and youth collectively remodel the values and beliefs that are important to the institution. Principals have to nurture the traditions, ceremonies, rituals and symbols that already express and reinforce positive school culture (Van Deventer \& Kruger, 2003: 24).

\section{The Voice of South African Traditional Healers}

Before 1994, sound health care administered by qualified personnel was inaccessible to the vast majority of South Africans. Still today, hospitals and clinics are not available to most black South Africans as well as growing numbers of whites. Health care is therefore largely in the hands of traditional healers who are disproportionately influential for that reason, so much so, in fact, that it is commonly believed they are capable of solving the most vexing social, political and economic problems by exercising the extraordinary powers ascribed to them for centuries (Van Dyk, 2008:212). Truter (2007) contends further that traditional healers' powerful role includes being a physician, counsellor, psychiatrist and priest, and people visit a traditional healer for problems ranging from social dilemmas to major medical illnesses. Traditional healers are so powerful and feared that few can challenge their authority despite the fact that most of them are not educated, live in poverty and communicate with the 'dead' in the course of their work.

Pope et al. (2009:260) note that The World Health Organisation defines the traditional healer as someone who has health practices, approaches, knowledge and beliefs incorporating plant, animal and mineral based medicine, spiritual therapies, manual techniques, and exercises. A traditional healer in the sense at issue is not a practitioner of "dark arts", a sorcerer in the medieval European sense, although people who claim to be healers also claim to be capable of sorcery. According to South Africa law, traditional healers are recognised as health practitioners by the Traditional Health Practitioners Act of 2008. Pope et al. (2009:261) confirm that traditional healers normally determine the cause of diseases as some kind of difficulty associated with the individual's interaction with his/her environment, or ancestral possession, or mischief made by evil spirits. According to Truter (2007) traditional medicine has at its base a deep belief in the interactions between spiritual and physical well-being, and therefore use a holistic approach in dealing with health and illness. This implies that the healer deals with the complete person, and provides treatment for physical, psychological, spiritual and social symptoms. Healers do not separate the natural from the spiritual, or the physical from the supernatural. 
In South Africa, twenty-five thousand traditional healers' medicines were submitted to the Medicines Control Council (MCC) in 2007 to be sanctioned for use in formal medical practice, however, the substances concerned were sanctioned without being tested scientifically (Cullinan \& Thom, 2009:148-149). One of the most notorious of these medicines, which was reportedly effective in treating HIV/AIDS, was 'Ubhejane'. One traditional healer, Zeblon Gwala, was interviewed by Ndaki (Cullinan\&Thom, 2009:152) concerning his famous HIV/AIDS concoction (Ubhejane). Gwala stated that he helped his patients through the dreams sent to him by guiding ancestors, who also guided him in the process of treatment, hence he could not divulge the ingredients used and the medication (Ubhejane) could not be subjected to scientific testing.

Some of the traditional healers assert that ARVs and traditional medicine are mutually incompatible. They also note that thousands of South Africans were influenced by the late Minister of Health, TshabalalaMsimang's scepticism about antiretroviral medication which was born of a stubborn refusal to acknowledge the validity of scientific medical practice, and proposed a diet of vegetables (Cullinan \& Thom, 2008:152).

The researchers stress that this reality in Africa is one of the major causes of the rapid increase in the HIV/AIDS propagation rate in South Africa. Failure to curb the HIV/AIDS propagation rate is attributed to the use of strategies and techniques that have been successful in other countries without duly considering their appropriateness under local South African conditions. The researchers believe that in this generation of scientific and technological advancement, anything that relies on the counsels of dead people (ancestral spirits), especially for the effective remediation of medical problems should be subjected to careful scrutiny. According to Youde (2007:2), given the epidemic HIV/AIDS statistics, the South African government should actively collaborate with international organisations that are recognised experts in the field and create best possible policies using educational institutions as a means of transmitting knowledge.

It is evident that HIV/AIDS education and behaviour are greatly influenced by popular beliefs. Beliefs on HIV/AIDS derive from deep understand of the characteristics and provenance of the disease, contrary to the strong ancestral beliefs that are guided by assumptions based on a revered deity. The researchers agree that factual HIV/AIDS education is the key to an effective remedy for the epidemic. The researchers agree with Cullinan and Thom (2009:156) that Tshabalala-Msimang's promotion of traditional medicine as an alternative to ARVs and the alliance she fostered with traditional healers was extremely irresponsible given her position in society.

Pope et al. (2009:261) note that there is no proof that the practices of self-styled "healers" among South African communities can cure or prevent infection with HIV/AIDS or that such practices have been known to work at any age in the past. Nevertheless there have been instances where South African traditional healers' medicines were reported to have had salutary effects on the progression of HIV/AIDS infection. Unfortunately the reports of such apparent effects seem anecdotal since no formal trials have been conducted that could bear out the claimed remedial effects and establish regimens for the treatment of HIV/AIDS with the medicines concerned. Pope et al. (2009:262) confirms that individuals suffer severe and sometimes lifethreatening effects after taking substances administered by South African traditional healers. Among the documented effects are bradycardia, brain damage, cardiogenic shock, diabetic coma, encephalopathy, heart rupture, intravascular haemolysis, liver failure, respiratory failure, toxic hepatitis and even death.

The table below shows an example of unconventional methods used by South African traditional healers who supposedly interpret the messages of the ancestors and the services of the conventional scientific medical doctors (Truter, 2007; Van Dyk, 2008 \& Cullinan \& Thom 2009: 152):

Juma (2001), Poku (2005) and Pope et al. (2009) confirms that traditional healers normally attribute the cause of diseases to a relational problem between individual persons and their environment, or to sorcery, or to ancestral spirit possession, or to some demonic agency (i.e. trading on atavistic fear of the unknown and suspicion of fellow human beings). Van Dyk (2008:202) and Truter (2007) agree that ancestor worship plays an extremely dominant role in the lives of many South African people. For them ancestors are like gods that protect and preserve the honour and traditions of a tribe. Despite the fact that the majority of South African traditional healers are uneducated or are moderately educated and living in poverty, they wield a great deal of power, fear and influence in South African punitive society. In some cases they command 
Table 1: Comparison between Conventional Doctor's Processes of Treating HIV/AIDS Versus South African Traditional Healers' Processes of Treating HIV/AIDS

\begin{tabular}{|c|c|}
\hline $\begin{array}{l}\text { CONVENTIONAL DOCTORS' PROCESSES OF } \\
\text { TREATING HIV/AIDS }\end{array}$ & $\begin{array}{l}\text { SOUTH AFRICAN TRADITIONAL HEALERS' (DIVINERS) PROCESSES OF } \\
\text { TREATING HIV/AIDS }\end{array}$ \\
\hline A doctor records the history of a patient. & $\begin{array}{l}\text { The illness or condition of a person is revealed to the traditional healer through three } \\
\text { methods of divination, casting of divination bones, mediumistic ability (clairvoyance } \\
\text { or telepathy) and through dreams and visions. }\end{array}$ \\
\hline $\begin{array}{l}\text { Physical examination is done using medical } \\
\text { equipment. }\end{array}$ & $\begin{array}{l}\text { Traditional healers' use divination to speak to the patient's ancestors to determine } \\
\text { what is making the patient ill. The ancestor diagnoses the condition and prescribes } \\
\text { the treatment that should be administered and tells the traditional healers what to do. }\end{array}$ \\
\hline Laboratory tests are done if required. & $\begin{array}{l}\text { Traditional medicine from an 'inyanga' is produced from raw, natural products (roots, } \\
\text { plants, leaves, etc). It is alleged that sometimes animal or human parts are used in } \\
\text { the medication, which is one of the reasons why some traditional healers do not } \\
\text { divulge the ingredients of their "medicine". Treatment includes psychosocial } \\
\text { counselling, simple surgical methods, rituals and symbolism. (The traditional healers } \\
\text { allege that everything they know is communicated to them by the ancestors and is } \\
\text { not produced by their own mental resources or expertise). }\end{array}$ \\
\hline Diagnosis is made. & $\begin{array}{l}\text { Traditional healers deal not only with the physical aspects of a person's condition but } \\
\text { focus on the mind and soul. They are claimed to render effective assistance towards } \\
\text { overcoming economic, social, psychological and political as well as health problems. }\end{array}$ \\
\hline $\begin{array}{l}\text { Prescription is given; which a licensed dispensing } \\
\text { doctor or pharmacist will use to dispense medicines. } \\
\text { Prescriptions give detailed information about the } \\
\text { contents of the medication being administered. }\end{array}$ & $\begin{array}{l}\text { Traditional healer claims competence to treat all ailments, including anything from } \\
\text { madness to influenza, as well as HIV/AIDS. No area is out of bounds for some } \\
\text { traditional healers. They also refer patients to other traditional healers in difficult } \\
\text { cases. }\end{array}$ \\
\hline $\begin{array}{l}\text { Ingredients of medicine, and side-effects that can be } \\
\text { experienced, are made known to the patient. }\end{array}$ & $\begin{array}{l}\text { Patients are given medication without labels and neither the frequency of } \\
\text { consumption of medication or indications of properly adjusted dosages or of the } \\
\text { dangers (side-effects) of the medicines or even the expiration dates of their } \\
\text { concoctions are given. Newspapers and old bottles are used as containers for the } \\
\text { medication. Most of the information pertaining to the medical treatment is given } \\
\text { orally. }\end{array}$ \\
\hline
\end{tabular}

inordinate respect and authority at least partly attributable to putative supernatural powers. Because of cultural beliefs, many South Africans will not be persuaded to use western medicine (Van Dyk, 2008:209).

The researchers agree with Van Dyk (2008:209) that traditional healers exert a powerful hold on the majority South African society. Some traditional healers have rare knowledge of herbal medicine which was handed down to them by generations of their forefathers in an unbroken oral tradition. In the absence of "western" medicine and treatment, herbal treatment has been extremely useful in treating ailments and diseases. Herbal remedies are not only used by South African communities, but are well-known to many nations as folk medicine. The problem, however, lies with the methods used and the beliefs propagated by the South African practitioners who administer these remedies, particularly where HIV/AIDS patients are concerned (Van Dyk, 2008:202-2003) that of consulting with ancestral spirits. Therefore, patients need a very specific treatment which cannot be neglected without endangering their lives.

Pope et al. (2009:260) state that many South Africans would choose traditional healers' medicine over allopathic western health care, as the existing public health care system is overstretched and cannot meet the needs of all who currently need it. About $70 \%$ of people in Africa rely on traditional medicine, and since the 1990s the World Health Organisation has advocated the inclusion of traditional healers as participants in HIV/AIDS prevention programmes (Van Dyk, 2008:212). The researchers believe that preventative HIV/AIDS education at schools could suffer a severe setback if this adjuration is implemented. There is clear evidence of the problems associated with using ancestral worship in solving medical problems and yet both the World Health Organisation and the South African state department of health are turning a blind eye (Cullinan \& Thom, 2009:154). As noted earlier, the 'status quo' is that learners are exposed to conflicting messages from their socio-cultural and their school environment as matters stand.

The researchers find that a potentially dangerous oversight has been perpetrated in failing to train traditional South African healers to handle HIV/AIDS with the necessary care and to advise their patients to immediately consult medical doctors for proper management and control of the disease. A crucial 
reason for this is simply that the formal medical sector is well-regulated as a profession where integrity is a crucial premium. The question is whether traditional or folk medicine is subject to the same vigorous scrutiny. The saying goes; where there's no complainant, there's no law. Healthcare workers cannot hide behind 'tradition' to protect them from scrutiny of the highest scientific standards in the public interest. This point cannot be over emphasised for anybody who ventures into the health-care domain; especially given the vast amounts spent in the formerly 'informal' sector of 'traditional' or 'folk' medicine.

The researchers are not is insensitive to spiritual beliefs, and that herbal medicine can be a source of healing for many ailments, but only on condition that such remedies undergo proper, rigorous research and development that meets international criteria and is duly accredited by the formal medical establishment. Development of organisational capacity and structure to achieve this is the main challenge in South Africa. In a school context leaders are needed who are clearsighted and dedicated to educating young learners in the $21^{\text {st }}$ century era about the dangers of HIV/AIDS.

\section{The Voice of the South African Government}

At the beginning of democracy in 1994, South Africa had a good history of government policies that support internationally recognised strategies for the treatment of HIV/AIDS. Unfortunately, Kalichman (2009: IX) reported that the by 2009 , the denialist government policy emanating from the Mbeki regime with respect to HIV/AIDS, cost of hundreds of thousands of lives. Confirming this, Harman and Lisk (2009:102) stated that there was evidence of a drastic crisis of government leadership concerning HIV/AIDS in South Africa. Cullinan and Thom (2009: Xi) also observe that people in prominent positions in government failed to acknowledge that a crisis was unfolding in South Africa. Instead of mounting massive support for South Africa's health crisis, President Mbeki and his Health Minister denied the HIV/AIDS problem or underplayed its severity or offered mere trifles (e.g. garlic, beetroot, lemons) to critical national health and economic problems from the some uneducated people in society who refuse to use scientific methods that have worked in other countries.

The South African government approved the Traditional Health Practitioners Act in 2008 to ensure that the traditional practitioners have a minimum standard of education. Cullinan and Thom (2009:148) noted that the Department of Health almost went to the extent of allowing herbal or traditional medicine to be distributed without being tested scientifically. As indicated earlier, the power that the traditional healers (sangomas) wield is undeniable. It is incomprehensible; however, that government turned a blind eye to the following issues:

- $\quad$ South African traditional healing practices are mostly enveloped in mystery and an ominous shock and awe atmosphere. Anyone questioning these beliefs is scorned and threatened with the wrath of the ancestors, which the practitioners of ancient arts will conjure into reality by fair means or foul.

- $\quad$ The belief about the power of dead ancestors as propagated by South African traditional healers is the main source of many popular misconceptions and general ignorance about HIV/AIDS, therefore most likely about the other dread diseases.

- Unwillingness of traditional healers to divulge the ingredients used in herbal or traditional medication without realising or acknowledging that a lack of transparency about such crucial matters has to militate strongly against their accreditation on par with conventional medical practitioners.

- A particularly pernicious characteristic of the practice of traditional healers is that it trades in fear, suspicion, paranoia, superstitious dread and the like, thus tending to entrench these qualities in the community whom they patronise.

- No scientific testing and registration of traditional medicine is enforced to ensure public safety as required by the World Health Organisation. Contrary to authoritative prescriptions for conventional medicines, traditional medicine is allowed to be distributed with no labels and dosage indications. Government officials confused the situation further by actively supporting the use of traditional medicines that have not been tested scientifically, are dispensed in unmarked containers and have ingredients that are unknown, except that they were putatively dictated to the dispenser in a dream for which the dispenser's word has to be taken (Cullinan \& Thom, 2009:148).

- Pope et al. (2009:262) note that in some instances people who take traditional medicine 
suffer severely from life-threatening effects such as bradycardia, brain damage, cardiogenic shock, diabetic coma, encephalopathy, heart rupture, intravascular, haemolysis, liver failure, respiratory failure and toxic hepatitis.

Youde $(2007: 80)$ states that, although Africa does need to find its own solutions to its own problems, many, many lives are being lost at incalculable cost to the country's development. It is crucial that HIV/AIDS techniques of prevention that have been successful in other countries be considered until a satisfactory local solution is found (i.e. that will save people's lives). The persistent devastating loss of human life caused by HIV/AIDS is totally unacceptable and unnecessary, and will therefore continue to be an obstacle to the achievement of sustainable development in South Africa.

In agreement, Squire (2007:27) states that the spread of HIV in South Africa is due to a combination of factors such as forced and voluntary migration, conditions of poverty, urbanisation, growing alcohol and drug abuse, needle sharing and reuse, the widespread non-acceptance of condoms, and lack of education. There is general consensus among researchers that popular beliefs, or rather, myths, about HIV/AIDS effectively add significant impetus to the spread of HIV/AIDS in Africa (Younde 2007, Van Dyk, 2008, Pope et al. 2009 and Cullinan \& Thom, 2009) in the sense that beliefs/myths stand in the way of the advancement of modern medical science as an effective weapon against the scourge HIV/AIDS. Despite this realisation, however, the main HIV/AIDS prevention strategies advocated/promoted in South Africa are condom use, abstinence and faithfulness to a single partner provided it is reciprocal (Van Dyk, 2008:209).

Local and international writers are strongly united in the view that culturally specific programmes are required to combat HIV/AIDS, especially in Africa. As noted by Van Dyk (2008:201), understanding the belief systems of South African communities is a prerequisite for administering therapeutic programmes according to modern medical science because judicious ways need to be sought to eliminate misconceptions and harmful superstitions so that effective treatment can proceed in the educational context. The state had failed to respond adequately to the HIV/AIDS pandemic in the past and WHO/UNAIDS/UNICEF (2010) echoed that:

The history of HIVIAIDS in the Republic of South Africa is perhaps the most controversial of any country. It is littered with examples of government inaction and harmful interference, pseudoscience, and conflict between politicians, HIVIAIDS organizations and scientists. The aftereffects of some two decades of counterproductive policies are still being felt today in a country that has the world's largest HIV epidemic.

Thus the question arises whether education managers can use school culture and effective educational methods of empowerment to eliminate or overcome counterproductive misconceptions concerning HIV/AIDS among learners in secondary schools. According to Wood (2008:29), HIV/AIDS impacts greatly on the quality of education, as it affects the learners, the educators as well as the teaching environment. Given of the latest envisaged goal of zero new infections as stated in the UNAIDS report on the global aids epidemic (2010:14), it has been realised that there is a need to focus on the societal structures, beliefs and value systems that present obstacles to effective HIV prevention efforts. Also included is poverty, gender inequity, inequity in the health care and education system, discrimination against marginalised people, and unequal allocation of resources ( of each of these is a significant problem in its own right).

\section{THEORETICAL FRAMEWORK}

The research under review is based on the learning theory of constructivism (Donald et al. 2010: 81-82; Bush, 2011: 37). It is a philosophy of learning which takes the social context into account and assesses the quality and effectiveness of the education process. The theoretical framework of constructivism posits that a person constructs his/her own reality and that all knowledge is socially constructed (Donald et al. 2010: 81-82; Bush, 2011: 37). This means that a person makes sense of phenomena by first interpreting what is happening and then acting on that interpretation. Barnett and Whitehead (2006) and Hall and Hord (2006) as well as Donald et al. (2010:81-82), agree that different social contexts and cultural patterns influence how children develop and how knowledge is not simply transmitted but actively constructed by an individual, groups and societies.

Donald et al. (2010: 81 - 82) and Adams, Cochrane and Dunne (2012), further contend that problems that a school faces need to be analysed and addressed within an understanding of broader social issues; particularly 
issues involving HIV/AIDS beliefs and misconceptions. Donald et al. (2010:81-82) argue in this regard that:

central concept in constructivist thinking is that knowledge is not fixed and given. It is shaped, constructed and re-constructed in different social contexts at different times.

As noted, the researchers argue that school principals have a primary role to be the main voice that leads learners to acquiring vital life skills, with specific reference to the theory of constructivism Adams, Cochrane and Dunne (2012). Moreover, learners are allowed to explore their environment, interact with it, and learn from it.

The constructivist educator acts as a prop and support for learners by recognising problems and devising solutions for them, rather than parroting information gleaned from the community. Therefore it is clear that school principals and teachers are the key to educating learners in a conducive school environment about HIV/AIDS (Maile, 2008: 65) and specifically in a secondary school context. In other words, a school environment, according to the researchers, where the learner feels emotionally safe and accepted as a unique individual is necessary.

\section{RESEARCH DESIGN AND METHODOLOGY}

The researchers adopted a phenomenological approach by making use of focus group interviews using open-ended questions. This qualitative design according to De Vos et al. (2005:88) and Mouton (2012: 55) would be the correct choice for the task in hand considering the sensitive nature of the topic which requires an approach that is best suited for gathering opinions and understanding beliefs, thus for determining how education has changed people's lives. This approach also allows the understanding and interpretation that subjects give to their everyday lives (De Vos et al. 2002:18; McMillan and Schumacher, 2010: 315-333). The research objectives were mainly pursuing naturalistic methods of study, analysing the conversations and interaction that researchers have with subjects. Cohen et al. (2008) confirm that understanding and describing culture involves making sense of the authentic gestures, displays, symbols, songs and way of life that give meaning to the group.

The object of the study under review was to determine how and to what extent school culture can be enlisted to overcome the pernicious effects of unfounded beliefs held by South African communities about HIV/AIDS. The qualitative research also sought to understand social life and the meaning that people attach to everyday life, with particular reference to combating the spread of HIV/AIDS in the secondary school environment (Cohen et al. 2008 \& De Vos et al. 2005:74).

\section{SAMPLING AND SELECTION OF PARTICIPANTS}

The main aim of data collection is to collect information that reveals participants' perceptions, ideas and beliefs in terms of their own experience of a particular subject. The researchers selected an urban secondary school in Pretoria, South Africa. The school was previously graded as Model A, predominately for white learners only. The participants namely, the school principal, educators and learners were purposely selected for data collection for the research. Out of a grade 12 school learners' population of eightynine (89) secondary school learners; twenty-four (24) were selected and divided into three focus groups. The focus groups of learners consisted of sixty percent white and forty percent black learners. This is significant because the majority of South African schools have a higher ratio of black learners. The target group of learner participants had basic characteristics in common: five years of high school education, overlapped by more than eight years' of comprehensive HIV/AIDS remediation training, including comprehensive HIV/AIDS studies and lifeskills coaching. The learners' understanding of the impact of HIV/AIDS is therefore critical for any campaign to combat the disease. The process involved face-to-face interview discussions with three structured groups of learners limited to eight (8) learners in each group. This group size was important in that it allowed individual members sufficient opportunity to participate actively.

A total of fourteen (14) teachers were also selected through purposive sampling (Creswell, 2013). They were also divided into two focus groups and each group was interviewed in consideration of the nature of the school culture existing at the selected school. The school principal was selected for a face-to -face interview as a means of triangulation of the information gathered from the focus group interviews with educators and learners. Successful sampling was achieved by securing the cooperation of the specific school principal.

\section{DATA COLLECTION TECHNIQUE}

The aim of data collection was to collect information that reveals participants' perceptions on the subject 
matter (Creswell 2014). The researchers selected an urban secondary school in Pretoria. The school principal, teachers and learners were the participants in the data collection for the research. The data collection strategies employed by the researchers included observation, interviewing using digital data recording. recording. The one-on-one interview with the school principal was conducted last using open -ended questions. This was done to ensure that some of the concerns or inputs from the learners and the teachers could be added to the questionnaire with the principal. The critical purpose of the interview was to assess the principal's role, which includes being the voice within the institution in the education of learners by managing the school culture. It was also important to ascertain whether and to what extent the principal understood the relationship between the school culture and popular beliefs and misconceptions about HIV/AIDS in the African context. The researchers divided the questions into main questions, probes and follow-up questions during the interviews.

Focus group interviews involve asking specific, wellplanned, open-ended questions to a group who can give informed ideas and opinions about the topic. The specific questions were unstructured and were sometimes modified during the course of the interview to obtain clarification of a point. Effective planning of the interviews was important to ensure a nurturing environment where the participants could feel comfortable and unpressured. De Vos et al. (2005:307) note that focus groups are especially useful in attempting to understand diversity. People feel relatively empowered and supported in a group situation where they are surrounded by others whom they see as their peers.

The collected data had to be processed before being analysed for meaning. To facilitate the data processing the researcher endeavoured to provide clear labelling and notes. Data collection processing included the use of colour coding, dating of the information, sequential numbering of focus groups, clear observation notes on the school culture and the interview setting. It was also important to organise the interview tapes and written notes immediately after the interview to avoid confusion and ensure complete retention of recorded material.

\section{DATA ANALYSIS}

The data analysis of the phenomenological study conducted in this instance entailed organising the data into themes and general descriptions of the experience analysed within a specific context according to Creswell and Plano (2007) and De Vos et al. (2002: 273). The trends and patterns from the data was analysed and interpreted. Data analysis is a challenging task that involves the combination of all the collected information into meaningful information that would answer the main research question.

The researchers analysed the data gained from interviewing participants, observations, and field notes by first transcribing it, reducing it by editing, segmenting, summarising, and open-coding (McMillan \& Schumacher, 2006; Punch, 2005 and De Vos et al. 2005). Data reduction was done without any significant loss of information. The data was organised in terms of frequently occurring categories. The data was grouped into themes and sub-themes from the interview data.

As noted by McMillan and Schumacher (2010:324), the validity of research refers to the degree of congruence between the explanations of the phenomena and the realities in the world. The degree in which the recorded interpretations were consonant with the meanings exchanged between the participants and the researchers was of extreme importance. The researchers took pains to ensure that the participants understood the questions being asked. The researchers also observed the school culture and the learner's mannerisms in the focus interviews as well as observed the unspoken mannerism and general behaviour of the learners at the school. The culture of the school is observable in learners' conduct around the school (e.g. the self -image they project in their speech and grooming). According to De Vos et al. (2005:339), the main issues on which validity and reliability depend are articulated in how credible, transferable, replicable, applicable and reflective of what participants discussed.

\section{ETHICAL CONSIDERATION}

It was important for the researchers to pay due attention to ethical considerations in the process of data collection. According to McMillan and Schumacher (2010:333) ethical guidelines include policies regarding informed consent, deception, confidentiality, anonymity, privacy and caring. Informed consent eliminates the issues of deception and violation of privacy.

The primary task was to obtain permission from all the relevant authorities namely The University of South Africa (UNISA), the educational institution and the 
participants. The participants were asked for their consent with due cognisance of all the relevant facts, of which they had been duly informed. Anonymity and confidentiality is a major ethical dilemma and requires the researchers to strike a balance between the demands made on them as professional scientists in pursuit of truth, and the potential threat posed to the participants by the research. As noted by Cohen, Manion and Morrison (2008:63) information collected by the researchers is sensitive as the information concentrates on a person's private life and beliefs if it falls within the private domain of the subject or poses a potential threat.

\section{PRESENTATION OF RESEARCH RESULTS}

\section{Introduction}

Four main themes emerged from a thematic inductive analysis of the transcripts. The themes are reasons for high HIV/AIDS statistics in South Africa, the impact of the voice of school culture on HIV/AIDS, the impact of the voice of ancestral worship on HIV/AIDS and strategies to improve HIV/AIDS education. Participants were given the same questions, in order to triangulate the meaning given to the phenomenon. The different themes are discussed below.

\section{Reasons for High HIV/AIDS Statistics in South Africa}

In terms of the reasons for high HIV/AIDS statistics in South Africa the following four sub-themes were identified from the participants' responses: environmental challenges, influence of traditional healers, the lack of formal HIV/AIDS education and limited access to medical assistance. All participants were asked the same research questions with slight variation.

The first sub-theme is the environmental challenges facing the South African society such as poverty, a culture of polygamy, moral degeneration of youths, and stigma were the main challenges in HIV/AIDS education. Learners agreed that some vast pools of jobless people are now using sex as a means of earning a living as a result of poverty. One learner commented that:

There are a lot of sex workers especially in towns, who are desperate to make a living. Many that are coming from rural areas do not have enough HIV/AIDS education.
Another learner emphasised the African culture of polygamy was rife and some traditionalists still believed that a man's wealth was measured by the number of wives and children he has. This made it difficult to curb the spread of HIV/AIDS, as this belief encourages multiple' sex partners and this also increases the level of poverty in the country.

The researchers posed the same question to educators who responded likewise stating that the male female relationships in Africa are different from other part of the developed countries. According to educators, poverty in South Africa makes it difficult for knowledge of HIV/AIDS to be disseminated in remote areas of the country, with the result that people living far from developed towns end up getting stale information that is not reliable. In support, another educator believes that poverty also exacerbates the falsification of the social grants being offered to singleparent families. Many poor people have more children in order to receive money from government and this can perpetuate unsafe sexual relations.

Second sub-theme captured the influence of traditional healers who are held in high esteem by many black African communities. According to another educator, they have also been given by government the official recognition on par with conventional medical practitioners, according to one educator. One of the youth was emphatic about the negative influence of traditional healers where HIV/AIDS was concerned.

\section{If a traditional healer says he/she can cure HIV/AIDS, no one is brave enough to challenge him}

In the same line of thinking another educator stated that many traditional healers proclaim an ability to cure HIV/AIDS through drawing healing powers from the patient's ancestral spirits by communicating with dead spirits. They perpetuate non-scientific beliefs/ misconceptions about HIV/AIDS. In agreement, the principal commented that the rights of the individual in South Africa had been over emphasised. The responsibilities that come with the rights were neglected, with the result that vital ethical and moral standards were compromised. The principal said, "People say it is my right to do this and that, but have they accepted the consequences of their rights?" People should accept the responsibilities associated with the rights they pursue.

The third sub-theme is that lack of formal education and recreation facilities cause critical problems in both 
rural and densely populated urban areas in South Africa. Learners felt that the lack of formal school education made it more difficult for people to understand how to prevent, diagnose and treat HIV/AIDS. One learner commented that, in South Africa, the rural areas lack recreation and entertainment facilities and this leads some people to indulge in casual sex and petty crime as a past time. One student commented that some people in rural areas use condoms as a saleable commodity instead of freely distributing them as a prophylactic.

In support, another learner commented that there is a general moral degradation in the country. Children give birth to children but cannot take care of themselves, let alone their children. The Principal was in agreement and felt that the media does not help in this deteriorating situation because of the amount of pornography available. HIV/AIDS was symptomatic of what was going on in society. The principal's opinion was that since 2004 the divorce rate in South Africa had begun to edge past the marriage rate. In his own opinion, this was indicative of the loosening of the moral fabric of society.

The fourth sub-theme is the limited access to medicial assistance as a result of few clinics and hospitals in the rural areas. One learner commented:

There is a problem of accessing HIV/AIDS testing centres even in urban areas. And people hide when they attend the centres available, because the stigma of the disease still exists. The people in the rural areas have problem accessing clinics or hospitals. The situation is really bad.

In the same line of thought, an educator in agreement stated that the availability of ARVS is problematic in rural areas due to lack of infrastructure for the easy management of HIV/AIDS treatment. There are very few rural hospitals or clinics where people can access HIV/AIDS treatment. The rural health situation has changed very little since independence in 1994.

\section{Impact of Voice of School Culture on HIV/AIDS Education}

The second theme was the impact of voice of school culture on HIV/AIDS. The participants were asked questions related to the different school activities for HIV/AIDS education and awareness. Four subthemes emerges namely, the overload of information on HIV/AIDS, behavioural changes due to formal HIV/AIDS education, school activities focusing on prevention of HIV/AIDS, and the need for increased training of educators on HIV/AIDS.

There seems to be information overload about HIV/AIDS at the school because of availability of internet and school HIV/AIDS curriculum at the school. This quality of the HIV/AIDS education in the secondary school is commendable as evident in this following excerpt from a learner:

We have received a lot of HIVIAIDS
education in different subjects such as Life
Orientation, Biology, Physical Science,
Business Studies and Sports. But some
most of these subjects like Life Orientation
does not go into depth about how this
virus attacks the body, the window period
after the initial infection by the virus and
how this ARV medication should be taken.
They (educators) focus too much on
prevention.

The principal commented that the school gave high priority to HIV/AIDS education and this has affected behavioural changes. Yet the input from society towards dealing with HIV/AIDS education has been minimal. The principal further indicated that the school tried to inculcate strong values in the learners. The educators were expected to take the lead in being role models. The school tried to cultivate leaders within the ranks of learners who could assist in dealing with problems and pressures faced by fellow learners.

In different focus group interviews, both the educators and learners spoke about the various activities conducted at the school to increase HIV/AIDS education as follows:

- The school curriculum directly and indirectly addressed the subject of HIV/AIDS, with the result that learners were well-informed about the virus and about relationship issues, particularly with regard to sex.

- $\quad$ The school has a disciplinary system that starts with the Executive Council of Learners (ECL), comprised of elected school prefects. The school also has a Representative Council of Learners (RCL) comprising class monitors. These class monitors are very effective and popular as agents to ensure a constructive, mutually beneficial partnership between the educators 
and learners in meting out discipline and maintaining order. Furthermore, the school also has a disciplinary system that moves away from punishing bad and rewarding good behaviour. Instead moral-value lessons are encouraged and moral behaviour is propagated moral behaviour.

- The school also has a Peer Support Group (PSG) that enables learners to contact their senior peers directly. Learners find it easier to discuss personal issues with their colleagues. Matters discussed varied across such issues as sexual relationships, bullying, drugs and peer pressure. PSG members are elected to engage in informal discussion of personal issues that affect students. If the issue is considered beyond the capacity and jurisdiction of the PSG the learner is referred to the school psychologist.

- The uniform dress code is unique and learners feel proud of their school. The school prefect ensures that everyone is dressed correctly and appears neat and tidy while on school premises.

- Learners have the opportunity every year to tour Europe and experience the way of life there. Many learners are able to benefit from this opportunity.

- School rules reward positive behaviour but sanction negative behaviour by imposing fines, for example R200 for smoking.

- There is a values period that all learners in the same age group are expected to attend once a week. It discourages negative behaviour and gives learners the opportunity to discuss sexual issues. The school usually invites a prominent person in society to address the school about social relationships.

- The school has a resident psychologist whom learners are free to consult for any psychological assistance they might need. The educators usually make the necessary arrangement for learners facing challenges to visit the resident school psychologist.

- Many sporting activities are available at the school to keep learners busy and out of mischief. These include swimming, rugby, cricket, tennis and table tennis. One of the male educators related how the school organised a number of activities during World AIDS Day to enhance learners' HIV/AIDS education. The school also organises blood donation during the World AIDS Day. Learners who were willing to donate blood were counselled and given information about the immune deficiency virus before donating blood.

- The level of qualified educators is high, which makes it easier for them to instil discipline. The school offers compulsory Life Orientation classes where educators are more than willing to discuss sex education with learners. Specific and detailed information about the propagation and treatment of HIV/AIDS is normally presented during Biology lessons. The Life Orientation classes focused on the social relationships and stigmas associated with HIV/AIDS

In support, the Life Orientation educator commented that:

\begin{abstract}
"the subject emphasises the morality and immorality points where relationships are concerned. Creative writing exercises done in the context of Life Orientation sometimes brings out the issues of abusive and ill-judged sexual relations and HIV/AIDS. It also brings out behavioural patterns and the reasons for such behaviours in society".
\end{abstract}

In the same line of thought the Business Studies educator confirmed that his subject looked at the effects of HIV/AIDS on business and the type of assistance business could render to people in general to lessen the impact of the disease on society. Generally speaking, HIV/AIDS education offered in the context of Business Studies did not go into detail about the AIDS virus (eg. as in Biology), but it did deal with corporate issues that are affected by sexual conduct.

\section{The Impact of Voice of Ancestral Worship on HIV/AIDS Education}

The impact of the voice of ancestral worship on HIV/AIDS education theme emerged dominant in the focus interviews with the learners and the educators. The sub-themes that emerged were the negative influence traditional healers on HIVA/AIDS, misconceptions about HIV/AIDS, and the belief of communication with the dead.

The educators agreed that the cultural practice of consulting traditional black African healers was a source of concern in light of its dubious methods and results, which were erratic and even harmful. One 
educator highlighted how traditional healers exploited people's superstitious dread and general ignorance has led to negative influence in the society where HIV/AIDS is concerned:

The traditional healers are held in referential awe by many people, especially in the black community. It's seen as a traditional practise because they have been the main source of wisdom for everything; from psychological problems, physical health and social issues.

The educators commented that misconceptions and false beliefs about HIV/AIDS derived from three sources, namely urban myths, oral tradition and black African traditional healers. Despite HIV/AIDS being a well-known disease, myths about its provenance and other characteristics such as prognosis persist due to ignorance caused by a lack of proper education among the vast majority of South Africans. The learners agreed that misconceptions about HIV/AIDS spread by traditional healers made it more difficult to manage HIV/AIDS in the rural areas. Rural dwellers end up relying on alternative sources of assistance like black African traditional healers, as interpreters; who are cheaper to consult and who are also considered reputable among some black African communities in South Africa.

Educators felt that the communication with the dead through traditional healers, as interpreters; who do not necessarily subscribe to scientific method is a critical challenge where HIV/AIDS education is concerned. The educators further commented that although the learners at their school laugh and scoff at these false beliefs and misconceptions, well-considered corrective responses should be formulated for learners' benefit. The reason why learners laugh is that they have acquired factual knowledge that shows up the absurdity of false beliefs and misconceptions about HIV/AIDS:

"There are challenges to all youths getting formal education in South Africa. It's possible that South Africa in particular, continues to have the highest HIV/AIDS infection and death rates of all countries, given our high prevalence of illiteracy which presents a formidable barrier to information campaigns to combat the disease."

The majority of the participants believed that the dead should not communicate with the living. Some learners in the focus group agreed it was a confusing issue since they sometimes dream of their dead loved ones, but do not necessarily seek guidance from them.

\section{Strategies to Improve HIV/AIDS Education}

The final forth theme was derived from the comments given by the participants. The educators proposed a number of solutions for improving HIV/AIDS education in schools and in the community at large as stipulated below:

- Every child in South Africa should be able to read and write. Governments should promote universal literacy as well as numeracy much more efficiently. The educators agreed that the school could contribute to curbing the spread of HIV/AIDS mainly by providing education that gives learners factual (ie. scientifically substantiated) information about HIV/AIDS.

- HIV/AIDS awareness campaigns should be increased, especially in areas beyond the reach of public media.

- Legislative measures should be enacted to ensure that campaigning is more transparent (eg. street advertising).

- The government, civil society and the school should join forces in their campaign of preventive education to curb the spread of HIV/AIDS so that they can act in unison and not contradict each other. The principal commented that South Africa lacked real leaders who could inspire learners to contribute positively to the upliftment of the society.

- $\quad$ The government should ensure that affordable health care is available to the general public to the extent that it actively contributes towards curbing and even reversing the spread of HIV/AIDS.

- Black African "traditional healers" (sangomas) should not be allowed to practice without restriction, especially where HIV/AIDS is concerned. The Principal stated that instead there were conflicting voices coming from learners' homes, peers, society (learners' communities), and especially from people in positions of political prominence who should be major role models. 
$\bullet$

The principal felt that social problems in families were the reason why the prevalence of HIV/AIDS was higher in Africa than anywhere else in the world and government should focus on these social ills. The principal comment is captured in the following extract;

You find children brought up in polygamous marriages; and we feel that this sets a bad example to children who see this as a way of life. It forces them to think that it is acceptable to be promiscuous because it leads to having large families that help to work in the fields thereby reducing the task of working long hours. Some children have one father and five stepmothers. Should HIVIAIDS strike them, the whole clan is obliterated. The issue of HIVAIDS education should not be left for the school alone. Parents as primary educators should be part of it. Polygamy in Africa did not offer solutions to how HIVIAIDS should be tackled; instead it posed an enhanced risk of infidelity compared to monogamous unions.

In the same line of thinking, educators felt that they too did not have adequate HIV/AIDS training to deal with HIV/AIDS, but school activities aimed at combating the spread of HIV/AIDS were deemed sufficient to deter learners from reckless sexual conduct. The teachers suggested that they should be allowed to undergo HIV/AIDS education and training during their teacher training at colleges, and they should continue to attend courses to keep abreast with the rest of the world in this regard.

\section{DISCUSSION OF THE RESULTS}

\section{The Role of South African Youth}

South African youth still face significant challenges such as high unemployment rates, high HIV infection rate and increase in youth- headed households for the ages 15-24 (UNFPA South Africa, 2015). However, today's youth are the generation who are privileged, for the first time in history, with a superabundance of information, communication and technology (ICT). They are even experiencing the brand-new phenomenon of information overload via internet, television, libraries, oral transmission and school. It is important to empower African youth to be skilled at recognising problems and devising solutions in the $21^{\text {st }}$ century era. South Africa's population is largely made up of young people; those who are below the age of 35 years constitute about $66 \%$ per cent of the total population. With over 54 million South Africans, 18.5 per cent are between the ages 10-19; and 24 per cent are aged 15-24 (Stats SA: 2015), mid-year population estimate.

The research showed that formal education had successfully taught youth to thoughtfully and critically interrogate the validity of popular misconceptions about HIV/AIDS and to be conversant with and fully appreciative of the basic facts about HIV/AIDS. The fact that the youth raised concerns regarding ancestor worship, professing that they did not subscribe to traditional beliefs is evident of critical thinking and lack of fear. Misconceptions about HIV/AIDS are therefore possible higher amongst the majority of South Africa's population who do not have proper access to education and health-care facilities. Their marginalised circumstances also render them susceptible to the influence of traditional healers who especially propagate misconceptions about HIV/AIDS.

It is a fact that most schools attended by South African youth are not characterised by an adequate and conducive learning environment poses a significant barrier to the dissemination of science-based HIV/AIDS education. Yet, some grade 12 learners (according to the study) are still able to find creative and innovative ways of obtaining the HIV/AIDS information that will separate them from the older generation who base their putative knowledge of HIV/AIDS on oral tradition, outdated culture, and consultation of ancestral spirits.

Each generation has to seek new ways of doing things in a better and more enlightened manner than its predecessors. In this age of global technology, creativity and innovation, it is a necessity and not a want or nice to have for learners to ask 'why?' Thus proclaiming an innate desire for and capability of selfimprovement within humans that leads to new inventions and technological advancement. The researchers view that when a new generation stands still and fails to contribute towards maintaining the developmental impetus of its society, as a result of fear, it becomes a "lost" or "forgotten" generation that compromises its own future.

\section{The Role of Educators in HIV/AIDS Education}

A number of strategies can be used by school managers to influence school culture with a view to 
inculcating positive behaviour. Schools should adopt a culture of openness in terms of HIV/AIDS testing, just as they are so open about the distribution of condoms. This would establish the incontrovertible fact in youth' mind that HIV/AIDS is a life-sapping epidemic that seriously undermines the quality and viability of communal life at an acceptable and civilised level.

The school educators should invite more positive role models who are HIV/AIDS positive to give a face to the disease by addressing the youth and explaining how the treatment works. It is only through extensive HIV/AIDS education delivered across the board that acceptance of appropriate treatment of HIV/AIDS according to international standards can be achieved. Without such an educational campaign conducted unremittingly throughout South Africa people will continue to die unnecessarily.

There is an urgent need for the services of specialised and highly competent educators whose exemplary conduct could serve as a role model for the young people. Without effective leaders the school culture would not be an effective educational tool for learner HIV/AIDS education. It is imperative that educators should speak with one voice were HIV/AIDS is concerned, especially in South Africa, which has twelve official languages. According to the educators, diversity, multiculturalism and ethnicity did not reduce the effectiveness of HIV/AIDS education provided at the school in question. The educators have a direct role to play in creating a conducive school culture for HIV/AIDS education and should use the resources at their disposal to empower youth to understand the facts about HIV/AIDS. The curriculum should provide accurate and appropriate HIV/AIDS information.

There is an urgent need for educators to be given regular and updated information on HIV/AIDS education in light of the dynamic $21^{\text {st }}$ century era of globalisation. The researchers agree with Van Dyk (2008:213) that secondary school educators should take cognisance of traditional beliefs held by and practiced among South African communities with a view to adopting formal educational strategies to wean learners away from misconceptions about HIV/AIDS.

\section{The Role of Society in HIV/AIDS Education}

In most African societies both political leaders and citizens are generally reluctant to discuss sex with young people. The image of AIDS as a sexually transmitted disease also contributes to the stigmatization of infected people, which in turn may cause many to avoid testing to determine their status. According to Lindner (2010: 54 ) society's contribution is essential for the development of adolescents' social skills so that they can become active and responsible members of their society and family. If the youth learn from their social milieu that HIV/AIDS is curable while the school gives out an opposing message, the net effect of such contradictory messages can be confusing for the recipient, with the result that the communication of the verifiable scientific facts may be lost on the child.

The society that encourages the learner to entrust his or her social, economic, health and political future to the dubious utterances of ancestral spirits as relayed by a self-appointed medium, instead of relying on properly qualified educational and other institutions that are duly tried and trusted purveyors of scientifically sound knowledge will always lag behind the developed world. South African traditional healers' methods of diagnosis and treatment of HIV/AIDS do not conform to those of modern medical science which have the benefit of formal checks and balances of the formal medical profession. South African traditional healers' influence is pervasive and powerful because for many years they were the primary caregivers in Africa. Their alleged communication with ancestors for medical advice makes it difficult for non-initiates to challenge them (i.e. their advice is unverifiable). The challenge for educators is: which voice should be used in HIV/AIDS education, that of ancestors or that of science, for the South African youth, who are already facing many challenges in this regard?

\section{Parental Involvement in HIV/AIDS Education}

The parental involvement in HIV/AIDS education involves giving a child a solid foundation of morals and positive social norms and this should not be the sole responsibility of educators. Parents or guardians should form a partnership with educators in giving a solid grounding in terms of moral precepts and positive socialisation (cf. Van Deventer \& Kruger, 2003:22). This calls for the establishment of a genuine culture of civic virtue. Empowerment of parents would avoid blame-shifting in response to problems faced by younger generation.

The school culture is there to build on prior positive lessons given by the parents. HIV/AIDS education must never be the sole responsibility of the school, however; consequently if a society is 'in denial' (Youde, 2007:1) or preserves a conspiracy of silence or stigma about 
HIV/AIDS, the result is inferior or stunted development in the area of education and socio-economic development. The root of the problem is that medical science cannot be overruled by subjective (i.e. uninformed) religious considerations (e.g. ancestor worship) without incurring a serious risk of harmful consequences for people who urgently need assistance from the science and technology of formal medical science. The risk at issue here is inherent in the practice of traditional healers who claim ancestral spirits as the authoritative and definitive source of their knowledge. The secretive unverifiable nature of South African traditional healers' practice is a serious inherent flaw that militates against its acceptance as sound medical practice Any medical diagnosis and treatment of HIV/AIDS that is purportedly effected through the agency of ancestral spirits cannot be taken seriously. A particularly pernicious characteristic of the practice of South African traditional healers is that it trades in fear, soothsaying, suspicion, paranoia, superstitious dread and the like, thus tending to entrench and elevate to inordinate prominence in the public consciousness these qualities in the relevant communities. The longterm retardant effect over a wide front of being ruled by such negative qualities is well documented.

To an alarming extent some South African communities, or sections of communities, who are parents are in denial about the effects of mistaken cultural beliefs concerning methods of diagnosis, treatment and prevention of HIV/AIDS. The literature review undertaken for this study revealed that only one out of every 200 members of the total population of South Africa depend on medical doctors or have access to them. Again, as noted earlier, this is a major reason why South African parents find it easier to contact traditional healers whose services are normally readily available and cheap (Van Dyk, 2008:212). Moreover, there is a persistently critical shortage of sufficiently trained medical staff and qualified doctors in urban and rural areas. To make matters worse, the facilities, where medical services are provided are located far from patients, and the medical equipment at these facilities are frequently dysfunctional. ARVs are distributed erratically or not at all in these institutions. Consequently, it is difficult to persuade parents supportive of divination that conventional medical practice is preferable to the dubious practices of local traditional healers who claim ancestral spirits as the infallible source of their knowledge, and that they can 'cure' HIV/AIDS, even though no such claim is made by mainstream medical science.

\section{SUMMARY AND CONCLUSION}

The study findings revealed that the effectiveness of school culture as a means of combating HIV/AIDS must not be underestimated, especially since it deals with young people who are receptive to new ideas. Effective exploitation of school culture will result in positive learner behaviour and a better understanding of HIV/AIDS. The school offers accessible and appropriate information which dismisses misinformation and beliefs, misconceptions or myths unfounded about HIV/AIDS. There is too much international and local research information in the extant literature that could serve as an irrefutable indication of why HIV /AIDS continues to take a heavy toll on South African and other mainly South African populations. A number of studies have directed attention to poverty, prostitution and gender inequality, as significant factors that counteract efforts to combat HIV/AIDS. As noted, significant evidence was found to the effect that the negative influence of traditional healers (sangomas) on efforts to curb the spread of HIV/AIDS should be taken seriously. Many researchers have recommended that traditional healers be co-opted into HIV/AIDS prevention programmes. If this should happen it might open doors for more extensive research on the use of divination as a means of gaining information for R\&D. However, the facts emerging from the study under review seem strongly counter indicative at this stage since the traditional healers insist being the intermediaries between the living and the dead; as this is their only means of treating any patients.

In light of extensive personal observation at close quarters, as well as the evidence of the present study, it must be concluded that the influence of traditional healers is the most significant barrier to gaining the upper hand in the fight against HIV/AIDS. The climate of fear, suspicion and paranoia that persistently radiates from traditional healers and envelops the community they serve claim to serve selflessly should be subjected to searching scrutiny. Traditional healers ("sangomas") in virtually all walks of life have ironically exerted a highly counterproductive influence on efforts to combat HIV/AIDS. They are held in such awe that the communities in which they ply their trade dare not speak out against them, yet there is evidence of the harmful effects of the ministrations they purvey.

The most urgent, indeed imperative obligation that has to be met in tackling the HIV/AIDS pandemic in Africa is to adopt legislation to declare it a criminal offence for any person to proclaim to the public at large 
that HIV/AIDS can be cured completely and that no intervention by the formal medical profession is required to treat the condition. Unless this matter is addressed conclusively many South African people will continue to dismiss the use of antiretroviral medication and advocate for traditional methods involving herbal remedies to 'cure' HIV/AIDS. The second challenge is to find means of upgrading the rural schools to be fully equipped with resources that are available at the school interviewed. Education is a powerful tool that has proved invaluable in all first-world economies, and there is no reason to doubt that it can succeed in Africa too. The new generation of South African youth across the board, must be allowed to challenge the status quo of the older generation's purported wisdom (i.e. consulting ancestral spirits) by involving themselves in innovative critical thinking and creativity in the global era of information, communication and technology. What is universally clear is that schools are in a unique position, and specifically the education managers, to change young people's attitudes and behaviour, and that where this potential is harnessed successfully the impact of the AIDS epidemic can be significantly reduced by effectively promoting a conducive school culture. It goes without saying that education in South Africa takes place in two spheres, not necessarily mutually enhancing, and persistently at odds with each other in their effect on learners' understanding of and attitude towards the critical issue of HIV/AIDS. In fact, it is commonly assumed that school culture will have a dominant influence on learners' behaviour, beliefs and actions because school hours take up the bulk of their day (Van Dyk, 2008:213), and that school culture should therefore be utilised to ensure that learners are proof against unfounded beliefs and misconceptions about HIV/AIDS; but strong remedial action is nevertheless essential. In the light of this, the conflicting voices in HIV/AIDS education of the South African youth should not be underestimated, as the school culture versus South Africa traditional healers using ancestral worship can have serious implications for the future of the youth.

\section{REFERENCES}

Adams, J., Cochrane, M.,\& Dunne, L. 2012. Applying Theory to Educational Research. An Introductory Approach with Case Studies: John Wiley-Blackwell.

Badenhorst, D.C. (Ed.). 2003. School management. The task and role of the school teacher. Pretoria: van Schaik: 17-50.

Barnett, T.V., \& Whiteside, A. 2006.AIDS in the twenty-first century. Diseases and globalization. $2^{\text {nd }}$ Edition. Fully Revised and Updated. London: Palgrave Macmillan: 2-30.
Berganani, T. 2001. Factors influencing condom usage among Cape Town High school youth. Thesis. South South African Studies. Cape Town: University of Cape Town: 14-40.

Bush, T., Bell, L., Bolam, R., Glatter, R., \& Ribbins, P. 1999. Educational management: redefining theory, policy and practise. London: Paul Chapman Publishing Ltd.: 184-185. http://dx.doi.org/10.4135/9781446219676

Cohen, L., Manion, L., \& Morrison, K. 2008. Research methods in education. $6^{\text {th }}$ edition. London: Routledge. 15(63):133-354.

Coleman, M., Graham-Jolly, M., \& Middle-Wood, D. 2003.Managing schools in south services. Managing the curriculum in South Africa. London School. Huddersfield: Charlesworth Group: 40-70.

Creswell.J.W. 2013. Research Design. $4^{\text {th }}$ edition. SAGE Publication.

Creswell, J.W., \& Plano Clark, V.I., 2007. Designing and conducting mixed-methods research. Thousand Oaks, CA. Sage

Cryer, P. 2006. The Research Student's Guide to Success. Third Edition. Poland: Open University Press: 8-19.

Cullinan, K., \& Thom, A. 2009. The virus, vitamins \& vegetables. The South South African HIV/AIDS mystery. Pretoria: Jacana Media. ix (x):149-154.

De Vos, A.S. (Editor), Strydom, H., Fouche, C.B., \&Delport, C.S.L. 2002. Research at grass root level. Pretoria: van Schaik: 18354.

De Vos, A.S. (Editor), Strydom, H., Fouche, C.B., \&Delport, C.S.L. 2005. Research at grass root level. Pretoria: Van Schaik: 74358.

Dickinson, D., 2004. Traditional healers and HIV-AIDS. Pretoria: South South African Labour Bulletin. Vol. 28, Iss 4, p.60-62.

Donald, D., Lazarus, L \& Lolwana, P. 2010. Educational Psychology in Social Context. $7^{\text {th }}$ Edition. Cape Town. Oxford University: Southern Africa.

Egan, J.P. 2005. HIV education for Adults. Califonia: Jossy-Bass: 1940.

Firestone, W.A., \& Wilson, B.L.1985. Using bureaucratic and cultural linkages to improve instruction: the principal's contribution. Educational Administration Quarterly, 21(2): 7 - 30. http://dx.doi.org/10.1177/0013161X85021002002

Government of South Africa (2010, January) The National Communication Survey on HIVIAIDS 2009. Pretoria: Government printer.

Government of South Africa (2007, 12th March) HIV and AIDS and STI Strategic Plan for South Africa, 2007-2011. Pretoria: Government printer.

Hall, G.E., \& Hord, S.M. 2006. Implementingchange.Patterns, Principles, and Potholes. $3^{\text {rd }}$ edition. New Jersey: Pearson Educational Inc.: 21-40.

Harman, S., and Lisk, F. 2009.Governance of HIV/AIDS. Making participation and accountability count. USA and Canada: Routledge: 1-102.

Harman, S. 2010. The World Bank and HIV/AIDS. Setting a global agenda. USA and Canada: Routledge: 1-22.

Jazzar, M., \& Algozzine, B. 2007. Keys to successful $21^{\text {st }}$ century educational leadership. USA: Pearson Educational Inc.: 100110.

Joubert, R., \& Farris, J.A. 2004. The Law of South Africa. Vol. 8. Part Two. Durban: Butterworth.

Juma. M. 2001. Coping with HIV/AIDS in education. Case studies in Kenya and Tanzania. London: Popular Wealth Secretariat: 11.

Karpicke, H., \& Murphuy, M.E. 1996. Productive school climate and school culture: principles working from the inside. NASSP Bulletin 80(576) $27-34$. http://dx.doi.org/10.1177/019263659608057606 
Kalichman, S. 2009. Denying AIDS. Conspiracy theories, pseudoscience, and human tragedy. New York: Copernicus Books, an imprint of Springer Science and Business Media: (ix)8-76.

Kruger, A.G. 2002. Managing the school as an organization. Pretoria: University of South Africa: 18-50.

Lindner, M. 2010. A child's mind required! Evaluation results on a health promoting initiative on AIDS and sex education for primary schools. Germany: Budrich Unipress Ltd. \& Farmington Hills: (15)130-49.

Marcus, T. 2002. Kissing the Cobra: sexuality and high risk in a generalized epidemic- a case study of white university youth. South African Journal of AIDS Research, 1(1): p. 23-33/ Swedish International Agency Pretoria: (SIDA). http://dx.doi.org/10.2989/16085906.2002.9626541

Maree, K. 2007(Editor). First steps in research. Pretoria: van Schaik: 20-261.

Maxwell, T.W., \& Ross, T.A.1991. School climate and school climate and culture. Journal of Educational Administration. 29 (2): 72 $-82$. http://dx.doi.org/10.1108/09578239110003309

McMillan, J.H., \& Schumacher, S. 2006. Research in education. Evidence-based inquiry. International Edition. $6^{\text {th }}$ Edition. Boston. Pearson Education: 315-333.

McMillan, J.H., \& Schumacher, S. 2010. Research in education. Evidence-based inquiry. International Edition. $6^{\text {th }}$ Edition. Boston. Pearson Education: 315-333.

Moletsane, R. 2002. What kind of future can we make: education, youth and HIVIAIDS? South African Studies. Durban. South African Studies: 30 - 55.

Mouton, J. 2002.Understanding Research. Pretoria: van Schaik. 10 45.

Mouton, J. 2012. Understanding Research. Pretoria: van Schaik.

Nattrass, N. 2004.The moral economy of AIDS in South Africa. Cambridge: Cambridge University Press: 24.

Nattrass, N. 2007. Mortal combat. AIDS denialiasim and the struggle for antiretrovirals in South Africa. Cambridge: Cambridge University Press: 35.

New World Translation of the Holy Scriptures. 1984. Brooklyn. New York. Watchtower Bible and Tract Society. 87(98), 103(880), $482-485$.

Okumbe, JA.1999. Educational management. Theory and practise. Nairobi: University Press: 86.

Owens, R.G. 2001.Organisational behaviour in education. Instructional leadership and school reform. $7^{\text {th }}$ Edition. New York: Allyn \& Bacon: 10-50.

Poku, N.K. 2005.Aids in Africa. How the poor are dying. Cambridge: Polity Press: 125.

Pope, C., White, T.R., \& Malow, R. 2009. HIV/AIDS. Global frontiers in prevention/intervention. New York: Routledge: 256-263. UNAIDS. The Gap Report. Regional snapshots: sub-Saharan Africa: 2014

Punch, K.F. 2005. Introduction to social research: Quantitative and qualitative approaches. London: SAGE publications limited.

Schneider, H., and J. Stein. 2001. 'Implementing AIDS Policy in PostApartheid South Africa', in Social Science and Medicine, 52: 723-731.

Skosana, MND. 2001. Perceptions of adolescents about sexuality and sexually transmitted Diseases. (Dissertation). Master of Arts. University of South Africa: 10-25.

South South African Government: Adult mortality (age 15-64) based on death notification data in South Africa: 1997-2004. Statistics South Africa (2006, September) Pretoria: Government printer.
South South African Government: Department Of Social Development. HIVIAIDS Case studies in South Africa. 2002. Pretoria: SOCDEV.

South South African Government: Human Sciences Research Council .2009. South South African National HIV prevalence, incidence, behaviour and communication survey, 2008: A turning tide among Teenagers? Pretoria: HSRC.

South South African Government: National Education Policy Act No. 27. 1996. Government Gazette, 24 April 1996. Volume 370. 17118:2. Pretoria: Government Printer.

South South African Government: National Survey 2005. Pretoria: Government printer.

South South African Government: The longer speech of Honourable D.A. Motsoaledi. Member of Parliament: Minister of Health at the National Assembly. 2010. Parliament of South Africa.

South South African Government: The Presidency - Republic of South Africa (2009, 1st December) Address by President Jacob Zuma on the occasion of World Aids Day; Pretoria Showgrounds.

South African Government: Traditional Health Practitioners Act. 2007. Government Gazette. 2008. Parliament of South Africa.

Squire, C. 2007. HIV in South Africa. Milton Park: Routledge Publishers: 27, 77-166.

Squelch, A. \& Lemmer, E.M. 1994. Eight keys to effective school management in South Africa. Durban: Southern Book Publishers: vii-14.

Swedish International Agency (SIDA). Journal of AIDS Research. 1(1): p. 23-33. Pretoria: SIDA

The Global Fund to fight AIDS, Tuberculosis and Malaria (September 2005). Grants to countries in Africa, Rounds 1- 5 Funding.

The World Bank: 2004: Education and HIV/AIDS. A sourcebook of HIV/AIDS prevention programs Washington: Government printer: 1-8.

The World Bank. 2008. The World Bank's commitment To HIV/AIDS in Africa. Our agenda for action, 2007-2011.Washington: Government printer.

Truter I. 2007.African traditional healers. Cultural and religious beliefs intertwined in a holistic way. SA Pharmaceutical Journal.

UNAIDS (2000, September). Collaboration with traditional healers I HIV/AIDs prevention and care in sub-Saharan Africa. A literature review. Best practice collection. Geneva Switzerland.

UNAIDS/WHO (2003, August). Reconciling antenatal clinic-based surveillance and population-based survey estimates of HIV prevalence in sub-Saharan Africa.

UNAIDS (2008).2008 Report on the Global AIDS epidemic. WHO library Cataloging- in-publication data. Geneva Switzerland.

UNAIDS (2010) UNAIDS report on the global AIDS epidemic. WHO library Cataloging- in-publication data. Geneva Switzerland.

UNAIDS (2013) UNAIDS report on the global AIDS epidemic. WHO library Cataloging- in-publication data. Geneva Switzerland.

Van Deventer, I., \& Kruger, A.G. 2003. An Educator's guide to school management skills. Pretoria: van Schaik: 9-14., 182.

Van der Westhuizen, P.C. 2004. Effective educational management. Cape Town: Kagiso Tertiary: 27.

Van der Westhuizen, P.C. (Ed.). 2007. School as an organization. Pretoria: van Schaik: 5-145.

Van Dyk, A. 2008. HIV/AIDS care and counselling. A multidisciplinary approach. $4^{\text {th }}$ Edition. Cape Town: Pearson Education: 2-213.

Whitehead, A., \& Sunter, C. 2000. AIDS. The challenge for South Africa. Cape Town: Human, Rousseau \& Tabelberg Publishers: 5-58. 
Wood, L. 2008. Dealing with HIV and AIDS in the classroom. Pretoria: Juta \& Company: 29-52.

WHO/UNAIDS/UNICEF (2010) Towards universal access: Scaling up priority HIVIAIDS interventions in the health sector. Washington DC: World Bank: 1.
UNFPA. 2014. Adolescents and youth. Retrieved $4^{\text {th }}$ October 2015.http://countryoffice.unfpa.org/southafrica/2013/04/22/66 09/youth/

Youde, R.J. 2007. AIDS, South Africa, and the politics of knowledge. New York:

DOI: http://dx.doi.org/10.6000/1929-4409.2016.05.12

(C) 2016 Siwela and Jansen; Licensee Lifescience Global.

This is an open access article licensed under the terms of the Creative Commons Attribution Non-Commercial License (http://creativecommons.org/licenses/by-nc/3.0/) which permits unrestricted, non-commercial use, distribution and reproduction in any medium, provided the work is properly cited. 